\title{
Molecular evidence for the polyphyletic origin of low pH adaptation in the genus Klebsormidium (Klebsormidiophyceae, Streptophyta)
}

\author{
Pavel Škaloud ${ }^{1}$, Alena Lukešová2 ${ }^{2}$, Veronica Malavasi ${ }^{3}$, \\ David Ryšánek ${ }^{1}$, Kristýna Hrčková² \& Fabio Rindi4 ${ }^{4, *}$
}

\begin{abstract}
${ }^{1}$ Department of Botany, Faculty of Science, Charles University of Prague, Benatska 2, CZ-12801, Prague, Czech Republic
${ }^{2}$ Institute of Soil Biology, Biology Centre v.v.i., Academy of Sciences of the Czech Republic, CZ-37005, České Budějovice, Czech Republic ${ }^{3}$ Research Unit of the National Interuniversity Consortium "The Chemistry for the Environment" and Interdepartmental Center of Environmental Science and Engineering (CINSA), University of Cagliari, Via San Giorgio 12, IT-09124, Cagliari, Italy

${ }^{4}$ Dipartimento di Scienze della Vita e dell'Ambiente, Università Politecnica delle Marche, Via Brecce Bianche, IT-60131, Ancona, Italy

*Author for correspondence: f.rindi@univpm.it
\end{abstract}

\begin{abstract}
Background and aims - Algae living in low $\mathrm{pH}$ environments have been the subject of numerous studies, but their phylogenetic relationships with relatives found in non-acidic habitats are poorly known. In the present study we analyzed the morphology and phylogeny of acid-adapted strains of Klebsormidium, a genus of filamentous green algae frequently present in low $\mathrm{pH}$ environments.

Methods - Eighteen strains of Klebsormidium were collected from from low $\mathrm{pH}$ habitats in Europe and U.S.A., mainly from terrestrial sites affected directly or indirectly by carbon mining activities. These algae were isolated in culture and their phylogenetic relationships were studied using $r b c \mathrm{~L}$ and ITS rDNA sequence data in a concatenated dataset.

Key results - In the molecular phylogeny the strains of Klebsormidium living in low $\mathrm{pH}$ habitats formed a polyphyletic assemblage. They were representative of sixteen lineages and corresponded morphologically to six species ( $K$. crenulatum, $K$. elegans, $K$. flaccidum, $K$. fluitans, $K$. nitens, $K$. scopulinum), with the exception of four strains for which an unambiguous identification was not possible.

Conclusions - The genus Klebsormidium is a group of morphologically and physiologically dynamic algae in which the capacity of adaptation to low $\mathrm{pH}$ conditions has been developed multiple times independently. Extreme acidophilic populations probably originate from populations of various species growing locally when strongly acidic habitats become available. For the acid-adapted lineages of Klebsormidium examined here the current known distribution is geographically restricted, with the exception of a lineage containing strains from Czech Republic, New Zealand and Ohio.
\end{abstract}

Key words - Acid mine drainage, acidophilic algae, acidotolerant algae, extremophiles, Klebsormidiales, Klebsormidium, molecular systematics, phylogeny, Streptophyta, taxonomy.

\section{INTRODUCTION}

Sites characterized by low $\mathrm{pH}$ conditions occur both in terrestrial and aquatic environments throughout the world. In a few cases the high acidity is due to natural geochemical and biological features of the areas in which these sites are located and is not caused by anthropogenic influences. Some well-known cases are represented by certain sites affected by volcanic activities (Baffico et al. 2004, Pollio et al. 2005), streams with naturally low $\mathrm{pH}$ produced by leaching of fumic and fluvic acids from podocarp rainforests (Novis \& Harding 2007) and rivers originating from areas with massive bodies of iron and copper sulfites (Aguilera et al. 2007a, 2007b). More often, however, the low $\mathrm{pH}$ is the result of human influence, mostly in the form of acid mine drainage released by mining activities (Lukešová 2001, Sabater et al. 2003, Novis \& Harding 2007). The extent of these effects is usually localized, and consequently the distribution of highly acidic habitats is patchy and fragmented (Gross 2000, Weisse et al. 2011). However, sites with low pH exist in all continents and the overall extent of these habitats on global scale is not negligible; for example, in the recent past it was considered that approximately $15,000 \mathrm{~km}$ of streams in the U.S. were affected by acid mine drainage (Gross 2000).

Highly acidic environments pose challenging conditions for algae and cyanobacteria not only due to the low $\mathrm{pH}$, but 
also because acidity is often combined with extreme levels of other parameters. High concentrations of heavy metals such as $\mathrm{Fe}, \mathrm{Cu}, \mathrm{Pb}, \mathrm{Al}$ and $\mathrm{Zn}$ are often recorded in soils and waters with low pH (Gross 2000, Aguilera et al. 2007b, Novis \& Harding 2007, Spijkerman \& Weithoff 2012), whereas at sites with geothermal activities acidity is accompanied by high temperatures (up to $83^{\circ} \mathrm{C}$; Huss et al. 2002, Pollio et al. 2005, Spijkerman \& Weithoff 2012). Additionally, most extremely acidic environments contain relatively low concentrations of dissolved organic carbon, and may therefore be considered oligotrophic (Johnson 1998), with further limitation for the growth of autotrophic organisms.

Due to such hostile conditions, the diversity of algae living in acidic environments is generally low (Huss et al. 2002, Sabater et al. 2003, Nancucheo \& Johnson 2012, Spijkerman \& Weithoff 2012), although some studies based on extended seasonal sampling and incorporating molecular data have revealed an unsuspected microbial eukaryotic diversity (Aguilera et al. 2006, 2007b). Organisms living in these environments can be separated into acidophiles (acidloving organisms, adapted to $\mathrm{pH}$ values as low as 0.05 and unable to grow at neutral $\mathrm{pH}$ ) and acidotolerant (acid-tolerating organisms, with growth optima at higher $\mathrm{pH}$ but able to tolerate low values) (Johnson 1998, Gross 2000). Some algal taxa are particularly able to adapt to low $\mathrm{pH}$ and are a recurrent presence in acidic habitats; these are mainly unicellular organisms such as species of the green algal genus Chlamydomonas, the euglenophyte Euglena, the chrysophyte Ochromonas, the diatom Pinnularia and red algae of the class Cyanidiophyceae (Johnson 1998, Huss et al. 2002, Ciniglia et al. 2004, Pollio et al. 2005, Novis \& Harding 2007, Spijkerman \& Weithoff 2012). However, some multicellular algae with filamentous habit may also occur in these habitats; of these, species of Klebsormidium P.C.Silva, Mattox \& Blackwell are the most frequently recorded. Members of this genus belong to the streptophyte lineage of the Viridiplantae (Leliaert et al. 2012) and consist of uniseriate filaments formed by cells having a parietal chloroplast with a single pyrenoid and reproducing asexually by biflagellate spores (Lokhorst 1996, John 2002). Klebsormidium is one of the most widespread genera of green algae in the world, spanning in distribution from polar to tropical regions and occurring in a wide range of terrestrial and freshwater habitats (Lokhorst 1996, Rindi et al. 2008, Škaloud \& Rindi 2013). Records of Klebsormidium in low pH habitats are available from many, widely separated locations all over the world, mainly in waters (Douglas et al. 1998, Stevens et al. 2001, Verb \& Vis 2001, Brown \& Wolfe 2006, Novis 2006, Valente \& Gomes 2007, Bray et al. 2008, Lear et al. 2009, Urrea-Clos \& Sabater 2009, Aguilera et al. 2010, Baffico 2010, Adlassnig et al. 2013) but also in soils (Lukešová \& Hoffman 1996, Lukešová 2001, Lukešová \& Hrčková 2011). Strains collected in low $\mathrm{pH}$ habitats are usually identified as Klebsormidium rivulare (Kütz.) M.O.Morison \& Sheath (Morison \& Sheath 1985, Stevens et al. 2001, Verb \& Vis 2001), Klebsormidium flaccidum (Kütz.) P.C.Silva, Mattox \& Blackwell (Lukešová \& Hoffman 1996, Lukešová 2001, Sabater et al. 2003) and Klebsormidium nitens (Meneghini) Lokhorst (Lukešová 2001). Novis (2006) described Klebsormidium acidophilum Novis based on collections made in low $\mathrm{pH}$ streams in New Zealand. However, a taxonomic assessment of Klebsormidium at species level is hampered by several unresolved issues and the precise identity of several species, including the type species $K$. flaccidum, remains uncertain (Novis 2006, Škaloud 2006, Rindi et al. 2008, 2011, Škaloud \& Rindi 2013). Currently, the molecular data available for strains of Klebsormidium from low $\mathrm{pH}$ habitats are limited, which is a major impediment for an assessment of their phylogenetic position and taxonomic identity.

Few studies have investigated the phylogenetic relationships between algae adapted to acidic conditions and their pH-neutral congeners. Besides the study of Novis (2006) for Klebsormidium acidophilum, results available for coccoid trebouxiophytes (Huss et al. 2002, Juárez et al. 2011) suggest that adaptation to low $\mathrm{pH}$ has taken place independently in different lineages and that in green microalgae acidophilic forms coexist with closely related neutrophilic forms. Here we investigate the phylogenetic relationships of low $\mathrm{pH}$ Klebsormidium using $r b c \mathrm{~L}$ and ITS sequences of several strains isolated from acidic soils and rivers in Europe and U.S.A. Using the phylogenetic framework built by previous molecular studies (Novis 2006, Mikhailyuk et al. 2008, Rindi et al. 2008, 2011, Škaloud \& Rindi 2013), our goal is to clarify whether adaptation to low $\mathrm{pH}$ in Klebsormidium is monophyletic or not and in which known lineages of this genus this trait occurs. The results have important implications both in terms of speciation patterns and from a biogeographic point of view.

\section{MATERIALS AND METHODS}

\section{Origin and isolation of Klebsormidium strains used in the study}

Eighteen strains of Klebsormidium were obtained from low $\mathrm{pH}$ terrestrial and aquatic habitats as detailed in table 1 . The strains were identified based both on morphological features (Printz 1964, Ettl \& Gärtner 1995, Lokhorst 1996) and molecular data from recent studies (Novis 2006, Mikhailyuk et al. 2008, Novis \& Visnovsky 2011, Rindi et al. 2011, Škaloud \& Rindi 2013). With the only exception of the strain from Ohio, all strains were isolated in unialgal cultures and DNA extractions were performed on cultured material. The two strains from Sardinia, Italy (SCCA009 and SCCA011) were isolated using WARIS-H culture medium without soil extract (McFadden \& Melkonian 1986). Stock cultures were established and maintained axenically at $25^{\circ} \mathrm{C}, 12: 12 \mathrm{~h} \mathrm{~L}: \mathrm{D}$, under cool white luminescent light $(80-100 \mu \mathrm{mol}$ photons $\mathrm{m}^{-2} \mathrm{~s}^{-1}$ ) in the Sardinian Culture Collection of Algae (SCCA), Interdepartmental Center of Environmental Science and Engineering (CINSA), University of Cagliari. The strains from Czech Republic and Germany were isolated in unialgal cultures using BBM culture medium (Andersen et al. 2005) and grown at $20-22^{\circ} \mathrm{C}, 18: 6 \mathrm{~h} \mathrm{~L}: \mathrm{D}$, under cool white luminescent light $\left(40-60 \mu \mathrm{mol}\right.$ photons $\left.\mathrm{m}^{-2} \mathrm{~s}^{-1}\right)$. Stock cultures are maintained at $15^{\circ} \mathrm{C}$ under continuous light below $10 \mu \mathrm{mol}$ photons $\mathrm{m}^{-2} \mathrm{~s}^{-1}$ in the Culture Collection of Soil Algae and Cyanobacteria at the Institute of Soil Biology, Academy of Sciences of the Czech Republic, České Budějovice. 


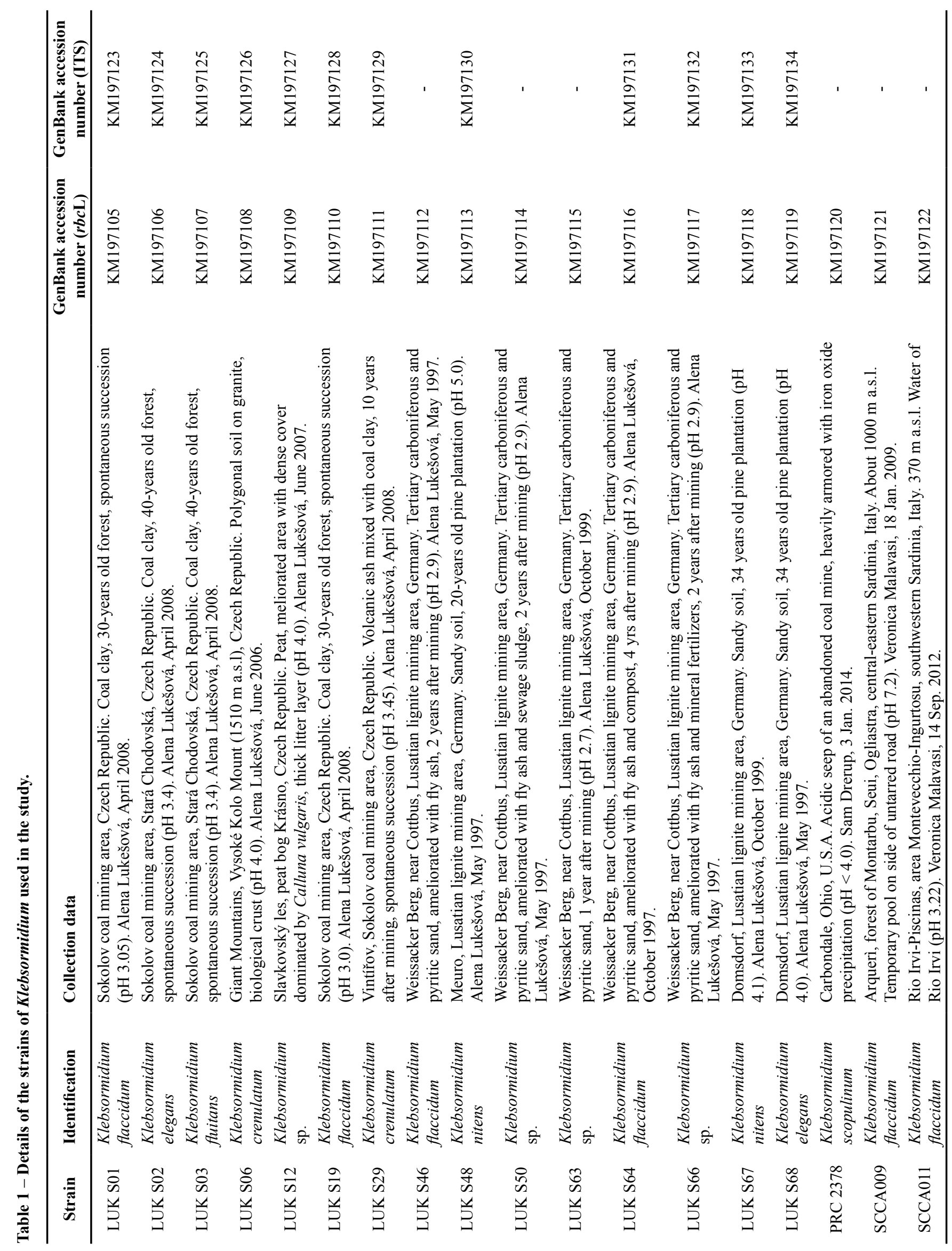




\section{DNA extraction, PCR and DNA sequencing}

Total genomic DNA was extracted from the fresh cultures or silica-dried material using the Invisorb ${ }^{\circledR}$ Spin Plant Mini Kit (Invitek, Berlin, Germany). Algal DNA was resuspended in sterile $\mathrm{dH}_{2} \mathrm{O}$ and amplified by polymerase chain reaction (PCR). The ITS1-5.8S-ITS2 rDNA region was amplified using the primers Klebs-ITS-F (5'-GGA AGG AGA AGT CGT AAC AAG G-3'; Škaloud \& Rindi 2013) and KlebsITS-R (5'-TCC TCC GCT TAG TAA TAT GC-3'; Škaloud \& Rindi 2013). The $r b c$ L gene was amplified using the primers $r b c$ L-KF2 (5'-ACT TAC TAC ACT CCT GAT TAT GA-3'; Škaloud \& Rindi 2013) and $r b c$ L-KR2 (5'-GGT TGC CTT CGC GAG CTA-3'; Škaloud \& Rindi 2013) or the primers $r b c$ L-KF376 (5'-TCA AAA CTT TCC AAG GTC CTC-3'; Rindi et al. 2008) and $r b c$ L-KR2. All PCR reactions were performed in $20 \mu \mathrm{l}$ reaction volumes, using the conditions described in Škaloud \& Rindi (2013). The purified amplification products were sequenced with the PCR primers using an Applied Biosystems (Seoul, Korea) automated sequencer (ABI 3730xl) at Macrogen Corp. in Seoul, Korea. Sequencing reads were assembled and edited using the SeqAssem programme (Hepperle 2004).

\section{Sequence alignment and model selection}

Multiple alignments of the newly determined ITS1 rDNA, ITS2 rDNA and $r b c \mathrm{~L}$ sequences and other sequences selected from the DDBJ/EMBL/GenBank databases (electronic appendix 1) were manually built using MEGA 4 (Kumar et al. 2008), and then optimized using MAFFT, version 6, applying the Q-INS-i strategy (Katoh et al. 2002). The concatenated data matrix of unique sequences was $1,672 \mathrm{bp}$ long and was $100 \%$ filled by the $r b c \mathrm{~L}$ data $(1,101 \mathrm{bp})$ and $79 \%$ filled by the ITS rDNA data $(571 \mathrm{bp})$. The concatenated alignment used for the phylogenetic analyses consisted of 84 sequences. Sequences retrieved from GenBank were selected in order to represent all lineages currently known in the phylogeny of the Klebsormidiales (based primarily on Rindi et al. 2011); whenever possible, we used strains for which both $r b c \mathrm{~L}$ and ITS sequence data were available. The appropriate substitution models for the ITS1 rDNA and ITS2 rDNA datasets and individual $r b c \mathrm{~L}$ codon positions were selected using jModelTest 2.1.4 (Darriba et al. 2012). This BIC-based model selection procedure selected the following models: (1) TIM2ef $+\Gamma$ for internal transcribed spacer ITS1, (2) K80 + $\Gamma$ for internal transcribed spacer ITS2, (3), TIM1 + I for the first codon position of the $r b c \mathrm{~L}$ gene, (4) JC + I for the second codon position of the $r b c \mathrm{~L}$ gene, and (5) TRN $+\mathrm{I}+\Gamma$ for the third codon position of the $r b c \mathrm{~L}$ gene.

\section{Phylogenetic analyses}

The phylogenetic tree was inferred by Bayesian inference (BI) using MrBayes version 3.2.1 (Ronquist et al. 2012). The analysis was carried out on a partitioned dataset using the different substitution models selected by jModelTest 2.1.4. The general structure of each substitution model was determined by the 'lset' command, and the model parameters were set using the priors defining the frequencies of nucleotides (statefreqpr) and nucleotide substitution rates (rev- matpr) using the Dirichlet distribution. All parameters were unlinked among partitions. Two parallel MCMC runs were carried out for five million generations, each with one cold and three heated chains. Trees and parameters were sampled every 100 generations. Convergence of the two cold chains was assessed during the run by calculating the average standard deviation of split frequencies (SDSF). The SDSF value between simultaneous runs was 0.00332 . Finally, the burn-in was determined using the 'sump' command. Variance around the parameter estimates were verified in order to ensure that they were effectively modelled. Bootstrap analyses were performed by maximum likelihood (ML) and weighted parsimony (wMP) criteria using GARLI, version 0.951 (Zwickl 2006) and PAUP*, version 4.0b10 (Swofford 2002), respectively. ML analyses consisted of rapid heuristic searches (100 pseudo-replicates) using automatic termination (genthreshfortopoterm command set to 100,000). The wMP bootstrapping (1,000 pseudo-replicates) was performed using heuristic searches with 100 random sequence addition replicates, tree bisection reconnection swapping, random addition of sequences, and gap characters treated as missing data.

\section{RESULTS}

The strains examined in this study were collected mostly from terrestrial habitats, primarily soils in areas affected directly or indirectly by carbon mining activities. Although at several of these sites carbon mining had ceased a long time before our surveys and the sites were subsequently subjected to a natural succession, the $\mathrm{pH}$ measured at the time of collection was still fairly acidic, ranging between 2.0 and 5.0 (table 1). The only algae obtained from aquatic habitats were the two strains from Sardinia (SCCA009 and SCCA011, Malavasi 2012), which were growing in water bodies with very different characteristics (the Rio Irvi, where SCCA011 was collected, is a river affected by mining drainage with extremely high levels of heavy metals, where the $\mathrm{pH}$ of the water was 3.22; the strain SCCA009 was isolated from a large temporary pool with $\mathrm{pH}$ close to neutral).

Our analyses revealed a great morphological and phylogenetic diversity of the strains of Klebsormidium examined (figs 1, 2 \& 3). Combining morphological observations and molecular data, they were referred to six species (K. crenulatum (Kütz.) Lokhorst (fig. 2A), K. elegans Lokhorst (fig. 2B), $K$. flaccidum (fig. 2C-E), K. fluitans (F.Gay) Lokhorst (fig. 2F), K. nitens (fig. 3A-B), K. scopulinum (Hazen) H.Ettl \& G.Gärtner), with the exception of four strains for which an unambiguous identification was not possible (fig. 3C-D). Details of the morphology of the strains are reported in table 2 . In the concatenated ITS1-ITS2-rbcL phylogeny, the low $\mathrm{pH}$ strains of Klebsormidium formed a polyphyletic assemblage (fig. 1). Overall, they were representative of sixteen lineages, which were separated in seven different clades belonging to four superclades delineated in recent studies (superclades D, E, F and $\mathrm{G}$ and clades E1, E2, E3, E4 as in Rindi et al. 2011 and Škaloud \& Rindi 2013) (fig. 1). Some of these evolutionary units corresponded to well-circumscribed morphological species and the strains from low $\mathrm{pH}$ habitats belonging to these units were in good morphological agreement with them: this was the case for the superclade D (corresponding 


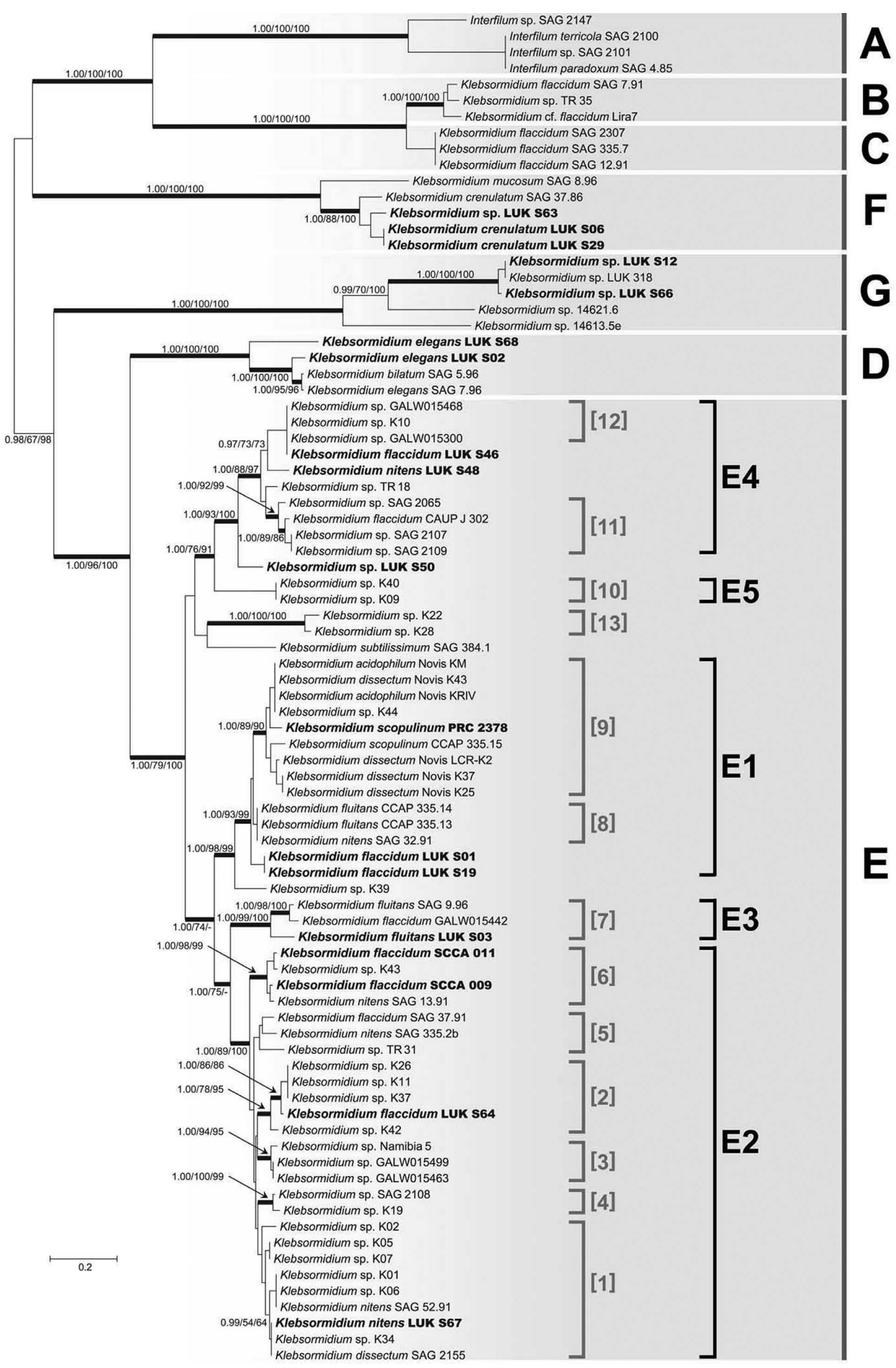

Figure 1 - Phylogram obtained from Bayesian analysis based on the combined $r b c \mathrm{~L}$ and ITS rDNA dataset, showing the position of investigated Klebsormidium strains and their relatives. Values at the nodes indicate statistical support estimated by MrBayes posterior node probability (left), maximum likelihood bootstrap (middle) and maximum parsimony bootstrap (right). Thick branches represent nodes receiving the highest PP support (1.00). Species affiliation to seven superclades (A-G) and five clades (E1-E5) sensu Rindi et al. (2011) is indicated, as well as the affiliation to 13 lineages sensu Škaloud \& Rindi (2013). Scale bar indicates number of substitutions per site. 


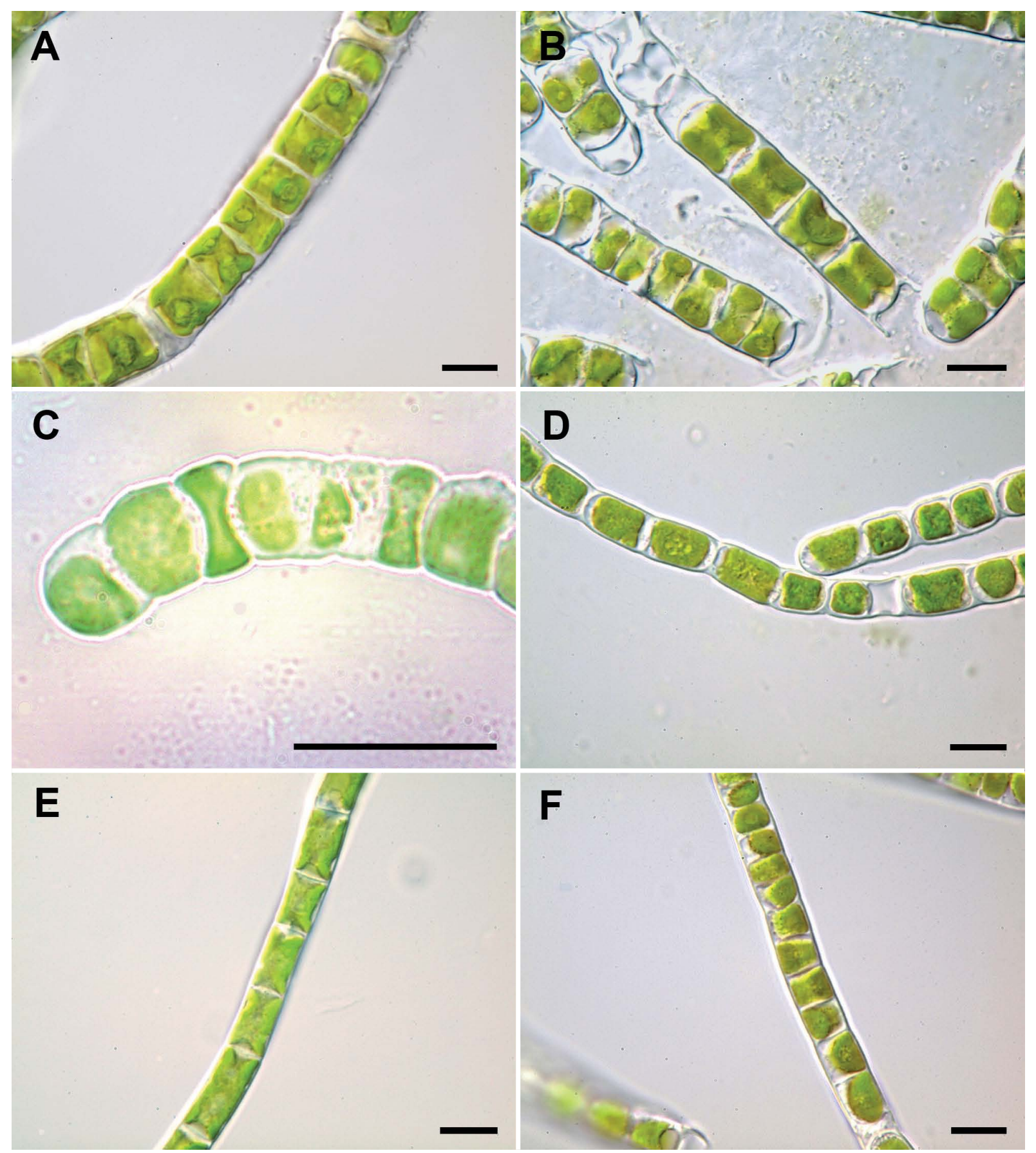

Figure 2 - Morphology of strains of Klebsormidium from low pH habitats: A, Klebsormidium crenulatum S06; B, Klebsormidium elegans S02; C, Klebsormidium flaccidum SCCA011; D, Klebsormidium flaccidum S19; E, Klebsormidium flaccidum S64; F, Klebsormidium fluitans S03. Scale bars represent $10 \mu \mathrm{m}$.

to $K$. elegans, fig. 2B), the superclade F (corresponding to $K$. crenulatum, fig. 2A) and the clade E3 (corresponding to $K$. fluitans, fig. 2F). Two unidentified strains (Klebsormidium sp. LUK S12 and LUK S66) belonged to the superclade G, a group discovered in recent molecular investigations (Rindi et al. 2011) and not yet resolved taxonomically; these strains displayed a key character typical of this superclade, the lobed chloroplast with a median incision (fig. 3D). Low $\mathrm{pH}$ strains identified morphologically as $K$. flaccidum belonged to the superclade $E$ but did not form a monophyletic group and were scattered in three separate clades (E1, E2, E4). The clade E2 included the two aquatic strains from Sardinia (SCCA009 and SCC011); although collected from habitats with different $\mathrm{pH}$ conditions, they were closely related and their $r b c \mathrm{~L}$ sequences differed by only a single nucleotide substitution. The two strains identified as $K$. nitens were not closely related and were recovered in separate clades (E2 and E4). The strain isolated from Ohio (PRC 2378) was identified as $K$. scopulinum and differed strikingly from all other strains for its markedly thin and long cells $(4.5-5.5 \mu \mathrm{m}$ wide, up to 10 


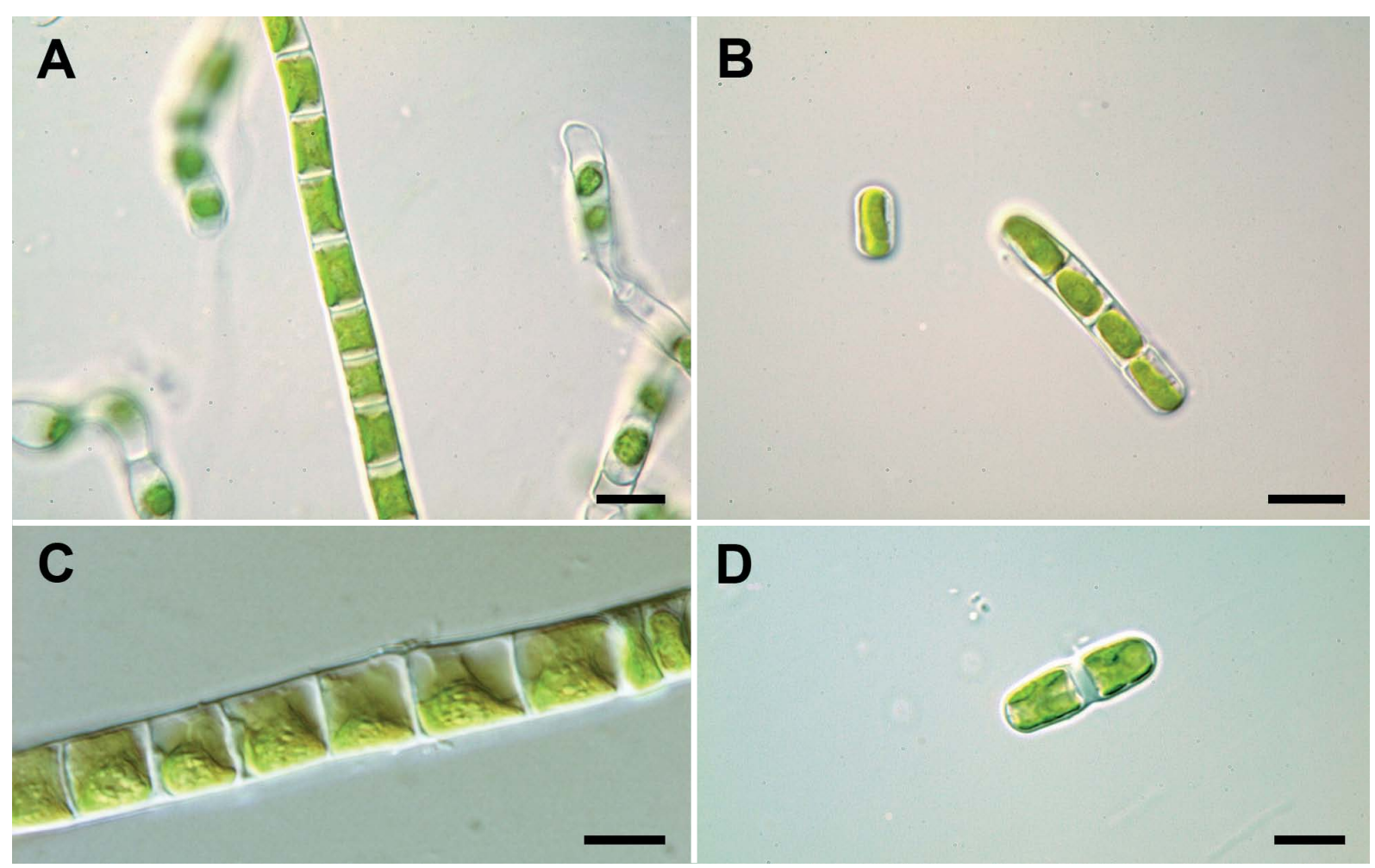

Figure 3 - Morphology of strains of Klebsormidium from low pH habitats: A, Klebsormidium nitens S48; B, Klebsormidium nitens S67; C, Klebsormidium sp. S50; D, Klebsormidium sp. S12. Scale bars represent $10 \mu \mathrm{m}$.

times as long as wide). Such morphological difference was accompanied by a sharp phylogenetic separation: in the molecular phylogeny PRC 2378 was clearly separated from all other strains from low $\mathrm{pH}$ habitats sequenced in this study. However, it was recovered with high support in a group including other acid-tolerant Klebsormidium (K. acidophilum from New Zealand sequenced by Novis 2006); it was also in close relationship with the only strain of $K$. scopulinum for which $r b c \mathrm{~L}$ and ITS sequence data were available (culture CCAP 335.15 isolated from the river Gannel, England).

Among our strains, only three had sequences identical to records already available in GenBank: Klebsormidium sp. LUK S12, K. flaccidum LUK S46 and K. nitens LUK S67. Therefore, most of the strains sequenced in this study appeared to be new lineages not detected in previous molecular studies, and some of them were remarkably distinct. Klebsormidium sp. LUK S50, in particular, was robustly placed in the superclade E but did not belong to any of the six clades delineated in this group in previous studies; it was recovered with high support as sister taxon to the clade E4. Two strains identified as K. flaccidum (LUK S01 and LUK S19) had identical $r b c \mathrm{~L}$ and ITS sequences; they belonged to the clade E1 but were distinct within it, representing the sister taxon to a clade formed by all other strains in this group.

Finally, it is worthy to note that none of the low $\mathrm{pH}$ Klebsormidium strains examined in this study and by Novis (2006) belonged to the superclades A, B and C. These groups include the genus Interfilum (superclade A), unidentified strains of Klebsormidium from natural habitats in eastern $\mathrm{Eu}-$ rope (superclade B) and several strains of $K$. flaccidum deposited in culture collections (superclade $\mathrm{C}$ ).

\section{DISCUSSION}

Our results clearly demonstrate that the capacity to adapt to low $\mathrm{pH}$ in Klebsormidium is phylogenetically widespread and does not represent a synapomorphy characterizing one or a few lineages. In our phylogeny, acid-adapted strains are widely interespersed among congeners living in habitats with neutral conditions. This situation is in agreement with the results of other phylogenetic studies focusing on microalgae from low $\mathrm{pH}$ environments, such as unicellular trebouxiophytes (Huss et al. 2002, Juarez et al. 2011), chlamydomonads (Gerloff-Elias et al. 2005, Pollio et al. 2005) and diatoms (Ciniglia et al. 2007). The fact that widely unrelated taxa possess the physiological and biochemical attributes that allow adaptation to low $\mathrm{pH}$ indicates that the genetic makeup on which these attributes are based is phylogenetically widespread among green algae. In the case of Klebsormidium this is not surprising, considering that members of this genus are equipped to withstand a wide range of extreme conditions and can grow in very hostile environments; records of Klebsormidium are available from biotic crusts of hot deserts (Lewis \& Lewis 2005), alpine soil crusts (Karsten et al. 2010), hydrothermal springs (Brown \& Wolfe 2006), Antarctic rocks and sand (Elster et al. 2008) and bases of concrete walls in trafficked urban streets (Rindi \& Guiry 2004). In this genus colonization and adaptation to low $\mathrm{pH}$ habitats seem to be frequent events, probably more frequent than in other green algal taxa. Based on the present study 


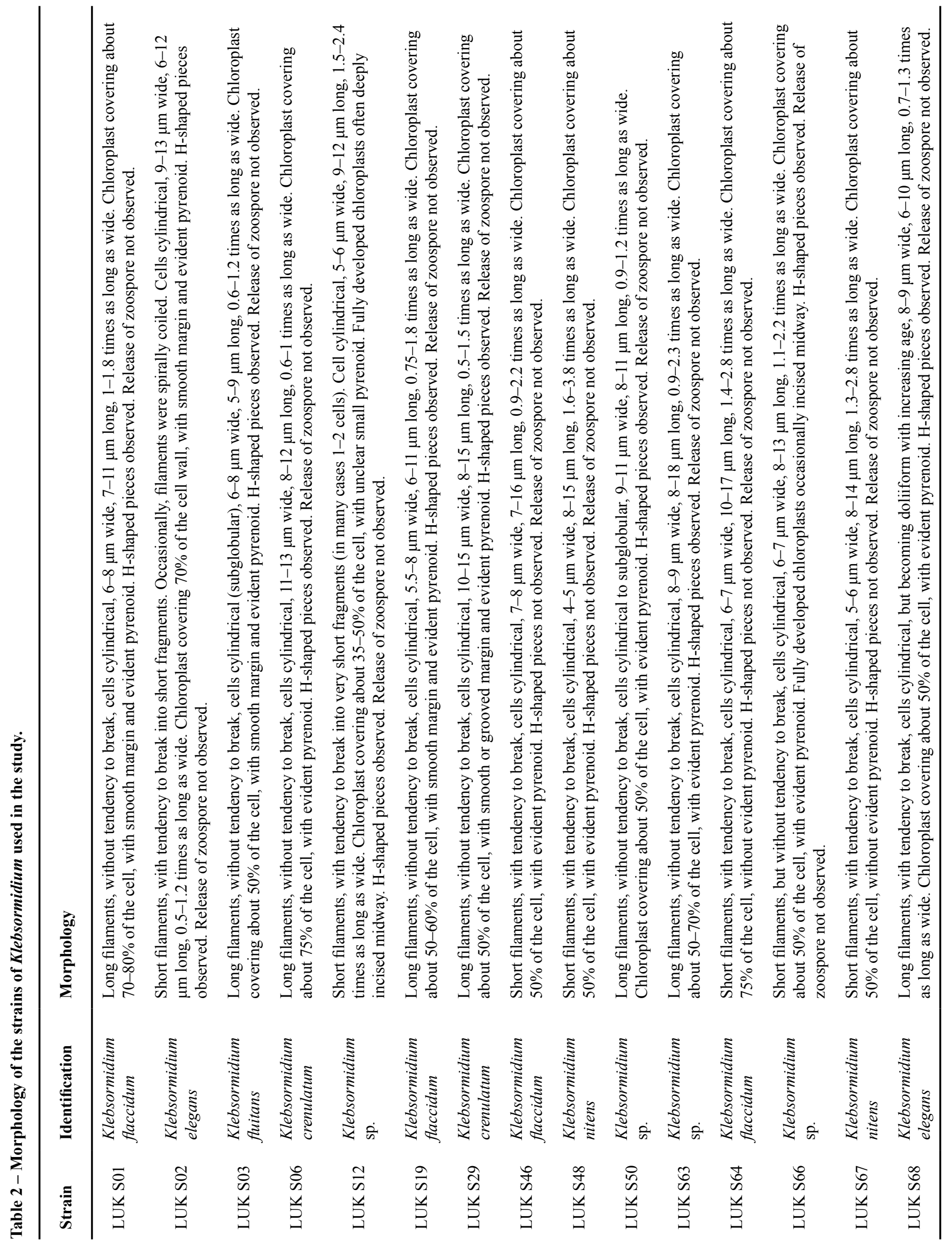


and the results of Novis (2006), at least sixteen lineages of Klebsormidium have adapted to life in acidic habitats; this is a higher number than for the other genera of green algae that have been investigated to date in this regard. The nature and extent of adaptation to low $\mathrm{pH}$, however, differ in different lineages. Some acid-adapted Klebsormidium strains are closely related to strains from non-acidic habitats; some have in fact identical or very similar $r b c \mathrm{~L}$ and ITS sequences to strains isolated from different environments, which is a strong indication of conspecificity. In these cases we are probably dealing with generalist species with large dispersal and wide $\mathrm{pH}$ tolerance, able to survive equally well in acidic and non-acidic environments. A situation of this type was demonstrated in other algae commonly found in low $\mathrm{pH}$ environments. For example, Parachlorella kessleri (Fott \& Nováková) Krienitz et al. isolated from a mesothermal acidic pond in Argentina ( $\mathrm{pH}$ 2.5-2.8) corresponded morphologically and had almost identical rDNA sequences to strains of the same species isolated from other environments (Juarez et al. 2011). The diatom Pinnularia obscura Krasske is considered a textbook example of an extremely acidotolerant species with global dispersal; strains from thermoacidic springs in Italy examined using morphological, ecophysiological and molecular data showed complete identity with strains from freshwater environments (Ciniglia et al. 2007). Conversely, other strains of Klebsormidium occurring in low $\mathrm{pH}$ environments are likely to represent evolutionary lineages that have genuinely evolved and specialized for life in acidic conditions. This type of scenario has been reported for other green algae considered real acidophilic organisms specialized for life at low $\mathrm{pH}$, such as strains of Chlamydomonas from thermal springs in Italy (Pollio et al. 2005) and acidic mining lakes in Germany (Gerloff-Elias et al. 2005) that grow optimally at $\mathrm{pH}$ values $<3$. In our phylogeny, good candidates are strains that form distinct lineages without a clear sister species/taxon, such as Klebsormidium sp. LUK S50, $K$. flaccidum LUK S01/LUK S19 and K. nitens LUK S48. We believe that these strains originated based on the hypothesis that extreme acidophilic populations establish from populations of various species growing locally when strongly acidic habitats become available. Other studies conducted in different environments have concluded that extreme conditions apparently unfavourable for survival and growth of green microalgae drive the evolution of these organisms (e.g. extreme aridity of North American deserts, Lewis \& Lewis 2005); it can be therefore expected that the same applies to strong acidity. This would also be consistent with the possibility suggested by Škaloud \& Rindi (2013) that selective sweep combined with the selection of new mutants differing in ecological niche may have played a major role in the differentiation of Klebsormidium. Physiological studies determining the optimal $\mathrm{pH}$ and the limits of the $\mathrm{pH}$ range in which different strains can grow would be very useful to understand better the nature and extent of adaptation to low $\mathrm{pH}$ conditions. Unfortunately, however, physiological data on acid adaptation in Klebsormidium are restricted to the experiments of Novis (2006) on $K$. acidophilum and $K$. dissectum from New Zealand. This is somewhat surprising, considering that Klebsormidium has been reported frequently in low $\mathrm{pH}$ habitats and that other aspects of the physiology 
of this genus have been studied with great detail in recent years (e.g. Elster et al. 2008, Nagao et al. 2008, Karsten et al. 2010, Karsten \& Rindi 2010, Kaplan et al. 2012, Karsten \& Holzinger 2012, Karsten et al. 2013). Novis (2006) found that both $K$. acidophilum and $K$. dissectum were able to grow in a similar range of $\mathrm{pH}$ (approximately 2.0 to 9.0 ), but the healthiest filaments of $K$. acidophilum were observed at $\mathrm{pH}$ 2.4 , whereas the healthiest filaments of $K$. dissectum were found at $\mathrm{pH}$ 4.8-6.2; combined with other morphological data, this supports the separation of $K$. acidophilum as a low $\mathrm{pH}$ species. Interestingly, other strains closely related to $K$. acidophilum examined in subsequent studies were collected from different geographical regions but also isolated from acidic environments: Klebsormidium sp. K44 from an acidic peat bog in the Czech Republic (Škaloud \& Rindi 2013) and K. scopulinum PRC 2378 (sequenced in this study) from the acidic seep of an abandoned coal mine in Ohio.

The idea that acid-adapted strains of Klebsormidium originate independently from generalist populations when acidic habitats become available is also partially supported by their high biogeographical diversity. It is remarkable that almost each acid-adapted lineage discovered in this study was restricted to a single site or a few sites in the same geographical area. At present none of these lineages appear to have a wide geographical distribution, with the only major exception of the lineage containing $K$. acidophilum and $K$. scopulinum (which, as mentioned above, includes strains from Czech Republic, New Zealand and Ohio). Biogeography and dispersal of acidophilic organisms are fascinating but poorly understood topics, and have been investigated in detail only for few taxa. Some authors concluded that acidophilic species have worldwide distribution (Gimmler 2001, Gerloff-Elias et al. 2005), conforming essentially to the neutral model of ubiquitous dispersal of microorganisms (everything is everywhere, but the environment selects; Baas Becking 1934). However, molecular studies that have focused on some acid-adapted morphospecies have unraveled genetic heterogeneity correlated to geographical distribution; cyanidialean red algae belonging to the genus Galdieria are the best-know example (Pinto et al. 2003, Ciniglia et al. 2004). Not surprisingly, this pattern is found in algae that are obligate acidophiles restricted to thermal acidic sites. An acidic environment is essential for the survival of these organisms, that cannot establish subpopulations in non-acidic habitats (Gross et al. 2001); their inability to reach easily other sites with suitable characteristics determines geographic isolation, with consequent high genetic differentiation (Ciniglia et al. 2004). The patterns observed for Klebsormidium conform to some extent to this situation; this may be an indication that many low $\mathrm{pH}$ Klebsormidium strains have reached a high level of specialization to acidic habitats, and do not disperse easily. This possibility, however, requires confirmation based on physiological data and further molecular sampling from other geographic regions. At the moment the data available for low $\mathrm{pH}$ strains are geographically biased (most of our strains are from central Europe) and sequence data of strains from other continents could reveal a different scenario.

The morphological identification of our strains based on characters traditionally used for species circumscription in Klebsormidium (Printz 1964, Ettl \& Gärtner 1995, Lok- horst 1996, John 2002) was straightforward for most of our strains. Our results, however, confirm the discrepancies between molecular phylogeny and morphology-based taxonomy evidenced by previous molecular studies (Mikhailyuk et al. 2008, Rindi et al. 2008, Novis \& Visnovsky 2011, Rindi et al. 2011). Some species, such as Klebsormidium crenulatum and $K$. elegans, can be linked unambiguously with molecular phylogenetic groups, and the low $\mathrm{pH}$ strains exhibitng the morphology of these species belong to the expected clades. Conversely, the morphology of the type species $K$. flaccidum is homoplasious and largely widespread in the phylogeny of the genus. This situation was already highlighted by previous studies (Rindi et al. 2011, Škaloud \& Rindi 2013) and is confirmed here: low $\mathrm{pH}$ strains morphologically referable to $K$. flaccidum belong to three different clades. The taxonomic circumscription of this species remains an open problem which cannot be solved by sequencing the type specimen, due to its poor quality (a small sample formed by a few filaments embedded in a drop of mud). Since the morphology of this species is so widespead in different clades, selection of a specimen from the type locality (Strasbourg, France) would also not guarantee to obtain the alga actually used for the description of the species (Kützing 1849). Therefore, the designation of an epitype specimen based on a subjective choice appears to be the only feasible solution of the reassessment of this species (Rindi et al. 2011). To a lesser extent, the same considerations apply to $K$. nitens, which is also polyphyletic; in this case, however, there is a phylogenetic group which appears a good candidate to be linked with this morphospecies (the clade E2, in which most strains referred to this species are recovered; Rindi et al. 2011, Škaloud \& Rindi 2013).

An interesting discovery of this study is the phylogenetic positioning of the strains LUK S12 and LUK S66 in the superclade $\mathrm{G}$. The superclade $\mathrm{G}$ represents a lineage recently discovered, formed mainly by strains isolated from biotic crusts of subdesertic areas in Namibia and South Africa (Rindi et al. 2011). Within this superclade, the strains LUK S12 and LUK S66 form a well-supported lineage with Klebsormidium sp. LUK 318, another strain isolated from eastern Europe (discarded material on soil previously subjected to coal mining in the Czech Republic). The two strains sequenced here exhibited a four-lobed chloroplast with a median incision, a character that appears to be diagnostic for this group. It will be very interesting to verify if this group has a wider geographical distribution and if it also occurs in different types of habitats; it can be expected, in particular, that strains of Klebsormidium from desertic areas in North America (Lewis \& Fletchner 2002, Lewis \& Lewis 2005) will turn out to belong to this superclade.

An additional point that requires some discussion is the high morphological plasticity related to environmental factors observed in Klebsormidium, an aspect that has complicated many morphological studies. It has been shown that the culture conditions and the age of cultures can significantly affect some morphological characters which were considered useful for species identification for a long time (Škaloud 2006, Rindi et al. 2008). The limited data available indicate that $\mathrm{pH}$ conditions may play a major role in this regard: Novis (2006) highlighted a strong effect of $\mathrm{pH}$ on the morphologies of $K$. acidophilum and $K$. dissectum, showing that 
characters such as cell shape, chloroplast shape and amount of granules deposited in the cytoplasm varied considerably in different $\mathrm{pH}$ conditions. Variations in $\mathrm{pH}$ are also known to affect cell shape in other green microalgae, mainly determining an overall reduction of the cell surface relative to the cell volume (Coesel 1982, Černá \& Neustupa 2010). This phenomenon is considered a functional response aimed at reducing osmotic stress. Algae living in low $\mathrm{pH}$ habitats are able to maintain a fairly constant, neutral, cytosolic $\mathrm{pH}$ over a wide range of external $\mathrm{pH}$ values (Gerloff-Elias et al. 2005, Bethmann \& Schönknecht 2009); the maintenance of a neutral cytosolic $\mathrm{pH}$ under low $\mathrm{pH}$ conditions is an energy-demanding process that involves considerable metabolic costs, and a reduced cell surface contributes to reducing these costs (Černá \& Neustupa 2010). Due to lack of experimental data, we are not able to demonstrate similar effects in our Klebsormidium strains and to assess their morphological variation in different $\mathrm{pH}$ conditions; we expect, however, that variations similar to those reported by Novis (2006) are probably general phenomenon.

In conclusion, the genus Klebsormidium is a morphologically and physiologically dynamic algal group in which the capacity of adaptation to low $\mathrm{pH}$ conditions has been developed multiple times independently. Further studies aimed at clarifying the extent of this adaptation and the molecular features that determine it have the potential to shed light into many fascinating aspects of the biology of acidophilic and acidotolerant organisms that are still poorly understood.

\section{SUPPLEMENTARY DATA}

Supplementary data are available in pdf at Plant Ecology and Evolution, Supplementary Data Site (http://www.ingentaconnect.com/content/botbel/plecevo.supp-data), and consist of additional sequences of Klebsormidiales used for the phylogenetic analyses.

\section{ACKNOWLEDGEMENTS}

We express our best wishes to our colleague Pierre Compère for his $80^{\text {th }}$ birthday and congratulate him for the achievements of his long and productive scientific career. We are very grateful to Sam Drerup and Morgan Vis for collecting and sending the strain of Klebsormidium scopulinum from Ohio. P. S. acknowledges financial support from Charles University Prague. V. M. gratefully acknowledges financial support from the Sardinia Regional Government (Italy) through the project "Master and Back - Percorsi di rientro" (P.O.R. Sardegna F.S.E. 2007-2013). The financial support of Research Unit of the National Interuniversity Consortium "The Chemistry for the Environment" and Interdepartmental Center of Environmental Science and Engineering (CINSA), University of Cagliari, is gratefully acknowledged. The work was also partly supported by "Fondazione Banco di Sardegna" (Sassari, Italy).

\section{REFERENCES}

Adlassnig W., Sassmann S., Lendl T., Wernitznig S., Hofhansl F., Lang I., Lichtscheidl I.K. (2013) Metal contamination and re- tention of the former mining site Schwarzwand (Salzburg, Austria). Applied Geochemistry 35: 196-206. http://dx.doi. org/10.1016/j.apgeochem.2013.04.012

Aguilera A., Amaral-Zettler L., Souza-Egipsy V., Zettler E., Amils R. (2007b) Eukaryotic community structure from Río Tinto (SW, Spain), a highly acidic river. In: Seckbach J. (ed.) Extremophilic algae, cyanobacteria and non-photosynthetic protists: from prokaryotes to astrobiology: 467-485. Dordrecht, Springer Verlag. http://dx.doi.org/10.1007/978-1-4020-6112$7 \_25$

Aguilera A., Gómez F., Lospitao E., Amils R. (2006) A molecular approach to the characterization of the eukaryotic communities of an extreme acidic environment: methods for DNA extraction and denaturing gradient gel electrophoresis analysis. Systematic and Applied Microbiology 29: 593-605. http://dx.doi. org/10.1016/j.syapm.2006.01.006

Aguilera A., Souza-Egipsy V., González-Toril E., Rendueles O., Amils R. (2010) Eukaryotic microbial diversity of phototrophic microbial mats in two Icelandic geothermal hot springs. International Microbiology 13: 21-32. http://dx.doi. org/10.2436/20.1501.01.108

Aguilera A., Zettler E., Gómez F., Amaral-Zettler L., Rodríguez N., Amils R. (2007a) Distribution and seasonal variability in the benthic eukaryotic community of Rio Tinto (SW, Spain), an acidic, high metal extreme environment. Systematic and Applied Microbiology 30: 531-546. http://dx.doi.org/10.1016/j. syapm.2007.05.003

Andersen R.A., Berges J.A., Harrison J.P., Watanabe M.M. (2005) Appendix A - Recipes for freshwater and seawater media. In: Andersen R.A. (ed.) Algal culturing techniques: 429-538. San Diego, Burlington \& London, Elsevier Academic Press.

Baas Becking L.G.M. (1934) Geobiologie of inleiding tot de milieukunde. The Hague, W.P. Van Stockum \& Zoon.

Baffico G. (2010) Epilithic algae distribution along a chemical gradient in a naturally acidic river, Rio Agro (Patagonia, Argentina). Microbial Ecology 59: 533-545. http://dx.doi.org/10.1007/ s00248-009-9627-4

Baffico G., Diaz M.M., Wenzel M.T., Koschorrek M., Schimmele M., Neu T.R., Pedrozo F. (2004) Community structure and photosynthetic activity of epilithon from a highly acidic $(\mathrm{pH} \leq 2)$ mountain stream in Patagonia, Argentina. Extremophiles 8: 465-475. http://dx.doi.org/10.1007/s00792-004-0408-1

Bethmann B., Schönknecht G. (2009) pH regulation in an acidophilic green alga - a quantitative analysis. New Phytologist 183: 327-339. http://dx.doi.org/10.1111/j.1469-8137.2009.02862.x

Bray J.P., Broady P.A., Niyogi D.K., Harding J.S. (2008) Periphyton communities in New Zealand streams impacted by acid mine drainage. Marine and Freshwater Research 59: 10841091. http://dx. doi.org/10.1071/MF08146

Brown P.A., Wolfe G.V. (2006) Protist genetic diversity in the acidic hydrothermal environments of Lassen Volcanic National Park, USA. Journal of Eukaryotic Microbiology 53: 420-431. http://dx.doi.org/10.1111/j.1550-7408.2006.00125.x

Černá K., Neustupa J. (2010) The pH-related morphological variations of two acidophilic species of Desmidiales (Viridiplantae) isolated from a lowland peat bog, Czech Republic. Aquatic Ecology 44: 409-419. http://dx.doi.org/10.1007/s10452-0099296-x

Ciniglia C., Yoon H.S., Pollio A., Pinto G., Bhattacharya D. (2004) Hidden biodiversity of the extremophilic Cyanidiales red algae. Molecular Ecology 13: 1827-1838. http://dx.doi.org/10.1111/ j.1365-294X.2004.02180.x 
Ciniglia C., Cennamo P., De Stefano M., Pinto G., Caputo P., Pollio A. (2007) Pinnularia obscura Krasske (Bacillariophyceae, Bacillariophyta) from acidic environments: characterization and comparison with other acid-tolerant Pinnularia species. Fundamental and Applied Limnology 170: 29-47. http://dx.doi. org/10.1127/1863-9135/2007/0170-0029

Coesel P.F.M. (1982) Structural characteristics and adaptations of desmid communities. Journal of Ecology 70: 163-177. http:// dx.doi.org/10.2307/2259871

Darriba D., Taboada G.L., Doallo R., Posada D. (2012) jModelTest 2: more models, new heuristics and parallel computing. Nature Methods 9: 772. http://dx.doi.org/10.1038/nmeth.2109

Douglas G.E., John D.M., Williamson D.B., Reid G. (1998) The aquatic algae associated with mining areas in Peninsula Malaysia and Sarawak: their composition, diversity and distribution. Nova Hedwigia 67: 189-211.

Elster J., Degma P., Kováčik L., Valentová L., Šramková K., Pereira A.B. (2008) Freezing and desiccation injury resistance in the filamentous green alga Klebsormidium from the Antarctic, Arctic and Slovakia. Biologia 63: 843-851. http://dx.doi.org/10.2478/ s11756-008-0111-2

Ettl H., Gärtner G. (1995) Syllabus der Boden-, Luft- und Flechtenalgen. Stuttgart, Jena and New York, Gustav Fischer Verlag.

Gerloff-Elias A., Spijkerman E., Pröschold T. (2005) Effect of external $\mathrm{pH}$ on the growth, photosynthesis and photosynthetic electron transport of Chlamydomonas acidophila Negoro, isolated from an extremely acidic lake (pH 2.6). Plant, Cell and Environment 28: 1218-1229. http://dx.doi.org/10.1111/j.1365$3040.2005 .01357 . \mathrm{x}$

Gimmler H. (2001) Acidophilic and acidotolerant algae. In: L.C. Rai, J.P. Gaur (eds) Algal Adaptation to Environmental Stresses Physiological, Biochemical and Molecular Mechanisms: 259290. Heidelberg, Springer Press.

Gross W. (2000) Ecophysiology of algae living in highly acidic environments. Hydrobiologia 433: 31-37. http://dx.doi. org/10.1023/A:1004054317446

Gross W., Heilmann I., Lenze D., Schnarrenberger C. (2001) Biogeography of the Cyanidiaceae (Rhodophyta) based on 18S ribosomal RNA sequence data. European Journal of Phycology 36: 275-280. http://dx.doi.org/ $0.1080 / 09670260110001735428$

Hepperle D. (2004) SeqAssem. A sequence analysis tool, contig assembler and trace data visualization tool for molecular sequences. Available from http://www.sequentix.de [accessed 20 Dec. 2011].

Huss V.A.R., Ciniglia C., Cennamo P., Cozzolino S., Pinto G., Pollio A. (2002) Phylogenetic relationships and taxonomic position of Chlorella-like isolates from low $\mathrm{pH}$ environments ( $\mathrm{pH}<3.0)$. BMC Evolutionary Biology 2: 13. http://dx.doi. org/10.1186/1471-2148-2-13

John D.M. (2002) Orders Chaetophorales, Klebsormidiales, Microsporales, Ulotrichales. In: John D.M., Whitton B.A., Brook A.J. (eds) The Freshwater Algal Flora of the British Isles: 433468. Cambridge, Cambridge University Press.

Johnson D.B. (1998) Biodiversity and ecology of acidophilic microorganisms. FEMS Microbiology Ecology 27: 307-317. http://dx.doi.org/10.1111/j.1574-6941.1998.tb00547.x

Juárez A.B., Vélez C.G., Iñiguez A.R., Martínez D.E., Rodríguez M.C., Vigna M.S., Molina M.D.R. (2011) A Parachlorella kessleri (Trebouxiophyceae, Chlorophyta) strain from an extremely acidic geothermal pond in Argentina. Phycologia 50: 413-421. http://dx.doi.org/10.2216/10-79.1

Kaplan F., Lewis L.A., Wastian J., Holzinger A. (2012) Plasmolysis effects and osmotic potential of two phylogenetically distinct alpine strains of Klebsormidium (Streptophyta). Protoplasma 249: 789-804. http://dx.doi.org/10.1007/s00709-011-0324-Z

Karsten U., Holzinger A. (2012) Light, temperature and desiccation effects on photosynthetic activity, and drought-induced ultrastructural changes in the green alga Klebsormidium dissectum (Streptophyta) from a high alpine soil crust. Microbial Ecology 63: 51-63. http://dx.doi.org/10.1007/s00248-011-9924-6

Karsten U., Lütz C., Holzinger A. (2010) Ecophysiological performance of the aeroterrestrial green alga Klebsormidium crenulatum (Charophyceae, Streptophyta) isolated from an alpine soil crust with an emphasis on desiccation stress. Journal of Phycology 46: 1187-1197. http://dx.doi.org/10.111/j.15298817.2010.00921.x

Karsten U., Pröschold T., Mikhailyuk T., Holzinger A. (2013) Photosynthetic performance of different genotypes of the green alga Klebsormidium sp. (Streptophyta) isolated from biological soil crusts of the Alps. Algological Studies 142: 45-62. http:// dx.doi.org/10.1127/1864-1318/2013/0102

Karsten U., Rindi F. (2010) Ecophysiological performance of an urban strain of the aeroterrestrial green alga Klebsormidium sp. (Klebsormidiales, Klebsormidiophyceae). European Journal of Phycology 45: 426-435. http://dx.doi.org/10.1080/09670262.2 010.498587

Katoh K., Misawa K., Kuma K., Miyata T. (2002) MAFFT: a novel method for rapid multiple sequence alignment based on fast Fourier transform. Nucleic Acids Research 30: 3059-3066. http://dx.doi.org/10.1093/nar/gkf436

Kumar S., Dudley J., Nei M., Tamura K. (2008) MEGA: a biologist-centric software for evolutionary analysis of DNA and protein sequences. Briefings in Bioinformatics 9: 299-306. http:// dx.doi.org/10.1093/bib/bbn017

Kützing F.T. (1849) Species algarum. Leipzig, F.A. Brockhaus.

Lear G., Niyogi D., Harding J., Dong Y.M., Lewis G. (2009) Biofilm bacterial community structure in streams affected by acid mine drainage. Applied and Environmental Microbiology 75: 3455-3460. http://dx.doi.org/10.1128/AEM.00274-09

Leliaert F., Smith D.R., Moreau H., Herron M., Verbruggen H., Delwiche C.F., De Clerck O. (2012) Phylogeny and molecular evolution of green algae. Critical Reviews in Plant Sciences 31: 1-46. http://dx.doi.org/10.1080/07352689.2011.615705

Lewis L.A., Flechtner V.R. (2002) Green algae (Chlorophyta) of desert microbiotic crusts: diversity of North American taxa. Taxon 51: 443-451. http://dx.doi.org/10.2307/1554857

Lewis L.A., Lewis P.O. (2005) Unearthing the molecular phylodiversity of desert soil green algae (Chlorophyta). Systematic Biology 54: 936-947. http://dx.doi.org/10.1080/10635150500354852

Lokhorst, G.M. (1996) Comparative taxonomic studies on the genus Klebsormidium (Charophyceae) in Europe. In: Julich W. (ed.) Cryptogamic Studies, vol. 5: 1-132. Stuttgart, Gustav Fischer.

Lukešová A. (2001) Soil algae in brown coal and lignite post-mining areas in central Europe (Czech Republic and Germany). Restoration Ecology 9: 341-350. http://dx.doi.org/10.1046/ j.1526-100X.2001.94002.x

Lukešová A., Hoffman L. (1996) Soil algae from acid rain impacted forest areas of the Krušné hory Mts. 1. Algal communities. Vegetatio 125: 123-136. http://dx.doi.org/ 0.100//BF00044646

Lukešová A, Hrčková K. (2011) Soil algae and cyanobacteria in post-coal mining sites in Europe and U.S.A. European Journal of Phycology 46 (Suppl. 1): 102.

Malavasi V. (2012) Contributo alla conoscenza delle microalghe d'acqua dolce dei Tacchi d'Ogliastra (Sardegna centro-orientale). Informatore Botanico Italiano 44: 321-328. 
McFadden G.I., Melkonian M. (1986) Use of Hepes buffer for microalgal culture media and fixation for electron microscopy. Phycologia 25: 551-557. http://dx.doi.org/10.2216/i0031-888425-4-551.1

Mikhailyuk T.I., Sluiman H.J., Massalski A., Mudimu O., Demchenko E.M., Kondratyuk S.Y., Friedl T. (2008) New streptophyte green algae from terrestrial habitats and an assessment of the genus Interfilum (Klebsormidiophyceae, Streptophyta). Journal of Phycology 44: 1586-1603. http://dx.doi.org/10.1111/ j.1529-8817.2008.00606.X

Morison M.O., Sheath R.G. (1985) Responses to desiccation stress by Klebsormidium rivulare (Ulotrichales, Chlorophyta) from a Rhode Island stream. Phycologia 24: 129-145. http://dx.doi. org/10.2216/i0031-8884-24-2-129.1

Nagao M., Matsui K., Uemura M. (2008) Klebsormidium flaccidum, a charophycean green alga, exhibits cold acclimation that is closely associated with compatible solute accumulation and ultrastructural changes. Plant Cell and Environment 31: 872-885. http://dx.doi.org/10.1111/j.1365-3040.2008.01804.x

Ňancucheo I., Johnson D.B. (2012) Acidophilic algae isolated from mine-impacted environments and their roles in sustaining heterotrophic acidophiles. Frontiers in Microbiology 3: 325. http:// dx.doi.org/10.3389/fmicb.2012.00325

Novis P.M. (2006) Taxonomy of Klebsormidium (Klebsormidiales, Charophyceae) in New Zealand streams and the significance of low-pH habitats. Phycologia 45: 293-301. http://dx.doi. org/10.2216/04-70.1

Novis P.M., Harding J.S. (2007) Extreme acidophiles: freshwater algae associated with acid mine drainage. In: Seckbach J. (ed.) Extremophilic algae, cyanobacteria and non-photosynthetic protists: from prokaryotes to astrobiology: 445-463. Dordrecht, Springer Verlag. http://dx.doi.org/10.1007/978-1-4020-61127_24

Novis P.M., Visnovsky G. (2011) Novel alpine algae for New Zealand: Klebsormidiales. New Zealand Journal of Botany 49: 339-349. http://dx.doi.org/10.1080/0028825X.2011.563423

Pinto G., Albertano P. Ciniglia C., Cozzolino S., Pollio A., Yoon H.S., Bhattacharya D. (2003) Comparative approaches to the taxonomy of the genus Galdieria Merola (Cyanidiales, Rhodophyta). Cryptogamie, Algologie 24: 13-32.

Pollio A., Cennamo P., Ciniglia C., De Stefano M., Pinto G., Huss V.A.R. (2005) Chlamydomonas pitschmannii Ettl, a little known species from thermoacidic environments. Protist 156: 287-302. http://dx.doi.org/10.1016/j.protis.2005.04.004

Printz H. (1964) Die Chaetophoralen der Binnengewässer. Eine systematische übersicht. Hydrobiologia 24: 1-376. http://dx.doi. org/10.1007/BF00170411

Rindi F., Guiry M.D. (2004) Composition and spatial variability of terrestrial algal assemblages occurring at the bases of urban walls in Europe. Phycologia 43: 225-235. http://dx.doi. org/10.2216/i0031-8884-43-3-225.1

Rindi F., Guiry M.D., López-Bautista J.M. (2008) Distribution, morphology and phylogeny of Klebsormidium (Klebsormidiales, Charophyceae) in urban environments in Europe. Journal of Phycology 44: 1529-1540. http://dx.doi.org/10.1111/1.15298817.2008.00593.x

Rindi F., Mikhailyuk T.I., Sluiman H.J., Friedl T., López-Bautista J.M. (2011) Phylogenetic relationships in Interfilum and Kleb- sormidium (Klebsormidiophyceae, Streptophyta). Molecular Phylogenetics and Evolution 58: 218-231. http://dx.doi. org/10.1016/j.ympev.2010.11.030

Ronquist F., Teslenko M., van der Mark P., Ayres D., Darling A., Höhna S., Larget B., Liu L., Suchard M. A., Huelsenbeck J. P. (2012) MrBayes 3.2: efficient Bayesian phylogenetic inference and model choice across a large model space. Systematic Biology 61, 539-542. http://dx.doi.org/10.1093/sysbio/sys029

Sabater S., Buchaca T., Cambra J., Catalan J., Guasch H., Ivorra N., Muñoz I., Navarro E., Real M., Romaní A. (2003) Structure and function of benthic algal communities in an extremely acid river. Journal of Phycology 39: 481-489. http://dx.doi. org/10.1046/j.1529-8817.2003.02104.X

Škaloud P. (2006) Variation and taxonomic significance of some morphological features in European strains of Klebsormidium. Nova Hedwigia 83: 533-550. http://dx.doi.org/10.1127/00295035/2006/0083-0533

Škaloud P., Rindi F. (2013) Ecological differentiation of cryptic species within an asexual protest morphospecies: a case study of filamentous green alga Klebsormidium (Streptophyta). Journal of Eukaryotic Microbiology 60: 350-362. http://dx.doi. org/10.1111/jeu.12040

Spijkerman E., Weithoff G. (2012) Acidic environments. In: Bell E.M. (ed.) Life at extremes: 364-379. Wallingford and Cambridge, CAB International.

Stevens A.E., McCarthy B.C., Vis M.L. (2001) Metal content of Klebsormidium-dominated (Chlorophyta) algal mats from acid mine drainage waters in southeastern Ohio. Journal of the Torrey Botanical Society 128: 226-233. http://dx.doi. org/10.2307/3088714

Swofford D.L. (2002) PAUP*. Phylogenetic Analysis Using Parsimony (*and Other Methods). Version 4. Sunderland, Massachusetts, Sinauer Associates.

Urrea-Clos G., Sabater S. (2009) Comparative studies of algal communities in acid and alkaline waters from Tinto, Odiel and Piedras river basins (SW Spain). Limnetica 28: 261-271.

Valente T.M., Gomes C.L. (2007) The role of two acidophilic algae as ecological indicators of acid mine drainage sites. Journal of Iberian Geology 33: 283-294.

Verb R.G., Vis M.L. (2001) Microalgal communities from an acid mine drainage impacted watershed. Aquatic Botany 71: 93-107. http://dx.doi.org/10.1016/S0304-3770(01)00184-X

Weisse T., Berendonk T., Kamjunke N., Moser M., Scheffel U., Stadler P., Weithoff G. (2011) significant habitat effects influence protist fitness: evidence for local adaptation from acidic mining lakes. Ecosphere 2: 1-14. http://dx.doi.org/10.1890/ ES11-00157.1

Zwickl D.J. (2006) Genetic algorithm approaches for the phylogenetic analysis of large biological sequence datasets under the maximum likelihood criterion. - PhD dissertation, University of Texas at Austin, Austin.

Manuscript received 12 Mar. 2014; accepted in revised version 25 Jul. 2014.

Communicating Editor: Bart Van de Vijver. 